\title{
TECHNICAL MILESTONES ON COGENERATION ENERGY PRODUCTION AT PAROSENI CENTRAL HEATING POWER PLANT
}

\author{
Racz Mihaela Dana, Radu Sorin Mihai, Petrilean Dan Codrut ${ }^{*}$ \\ University of Petroșani, 332006, Romania, e-mail: dcpetrilean@yahoo.com
}

\begin{abstract}
The production of electricity in Romania, from the beginning until today, was based on central heating power plants, mainly with its own energy resources. Power Plant Paroseni operates under subcritical parameters, it is part of the National Energy System and has the objective of producing thermal energy for the cities of the Jiu Valley and electricity supplied to the National Energy System. The purpose of the paper is to present historical and technical references regarding its structure and functioning.
\end{abstract}

Keywords: Paroseni central heating power plant, cogeneration history, energy.

\section{Short history of Paroseni Central Heating Power Plant}

Paroseni CHPP is a central heating power station which produces electricity and heat using black coal mined from Jiu Valley as fuel and natural gas for ignition and to maintain the flame.

In June 1952 the Ministry of Electric Energy - The Institute for Energetic Studies and Design the Thermo-energetic Sector, according to the provisions of the "10 Year Electrification Plan" (1951-1960) of Romania, created, (using a design of the Moscow TEP Institute), the technical design of Paroseni Electric Plant, the future I.C.T. of Paroşeni, while in 1953 the site management was set up for the construction of the I.C.T. Paroşeni.

First Step - In 1956 the first energetic of $50 \mathrm{MW}$, and during the period comprised between 1957 and 19592 more energetic groups of $50 \mathrm{MW}$ were turned on, groups which were operational until 2010, at present the groups are made redundant and their value reclaimed (fig. 1).

Second Step - In 1964 group no. 4 of $150 \mathrm{MW}$ was made operational, group which was the largest at that time. In 1989, the 150 MW group was stopped in order to update the technology. The technology update ended in August 2007, date when the energetic group operated within S.E.N (fig. 2) .

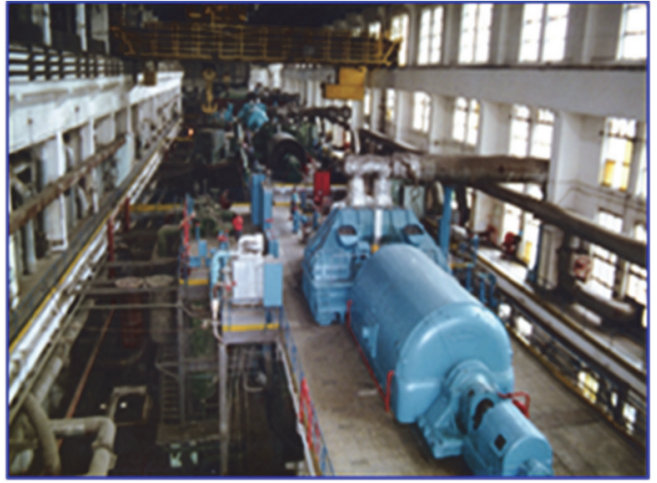

Figure 1. Electricity generator and steam turbine, $50 \mathrm{MW}$ group

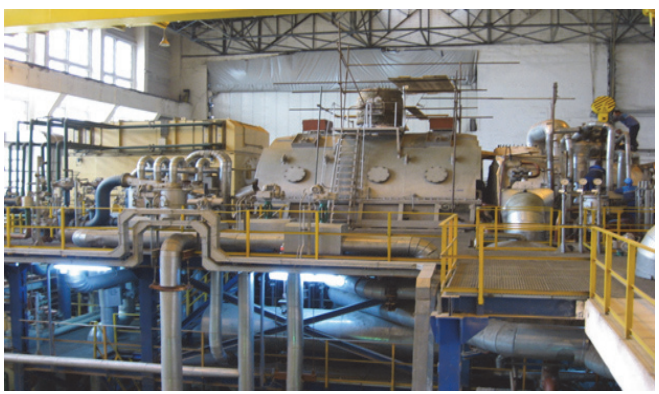

Figure 2. Electricity generator and steam turbine, $150 \mathrm{MW}$ group

Modernization of the central heating power plant

After a 50 years operational period given 
the conditions of a free energetic market, a renewal of the energetic capacity in Paroseni and for the non-viable units to be made redundant (i.e. three groups of $50 \mathrm{MW}$ each) was absolutely required as well as for the renewal of the technology of group 4 of $150 \mathrm{MW}$ in order to meet the specific conditions imposed by the developments brought forward by "Romania's Energetic Strategy" and "Romania's Energetic Pathway".

\section{The production capacities of Paroseni Power Station branches}

The Paroseni Power station branch operates a state-of-the-art Energy Unit of 150 MW. The rehabilitation of the energy unit no. 4 was carried out with an investment of 496,363,713.84 lei. The present production capacity of Paroseni Power station is presented in Table 1:

Table 1. Equipment of the $150 \mathrm{MW}$ group

\begin{tabular}{|c|c|c|c|c|}
\hline \begin{tabular}{l|c} 
N & Equipme \\
o & nt
\end{tabular} & $\begin{array}{l}\text { Nomi } \\
\text { nal } \\
\text { capac } \\
\text { ity }\end{array}$ & $\begin{array}{c}\text { Manuf } \\
\text { acture } \\
\mathbf{r}\end{array}$ & $\begin{array}{c}\text { Sta } \\
\text { rt } \\
\text { up }\end{array}$ & $\begin{array}{c}\text { Fue } \\
1\end{array}$ \\
\hline $1 \begin{array}{l}\text { Steam } \\
\text { cauldron } \\
\text { no. } 4\end{array}$ & $\begin{array}{l}540 \\
\mathrm{t} / \mathrm{h}\end{array}$ & $\begin{array}{l}\text { Babcoc } \\
\text { k } \\
\text { Hitachi }\end{array}$ & $\begin{array}{l}20 \\
07\end{array}$ & $\begin{array}{c}\text { Blac } \\
\mathrm{k} \\
\text { coal } \\
\text { / gas } \\
\end{array}$ \\
\hline $2 \begin{array}{l}\text { Cogenerat } \\
\text { ion steam } \\
\text { turbine } \\
\text { no. } 4\end{array}$ & $\begin{array}{c}150 \\
\mathrm{MW} / \\
150 \\
\mathrm{Gal} / \mathrm{h}\end{array}$ & $\begin{array}{l}\text { TURB } \\
\text { OATO } \\
\mathrm{M}- \\
\text { Ukrain } \\
\mathrm{e}\end{array}$ & $\begin{array}{l}20 \\
07\end{array}$ & \\
\hline $3 \begin{array}{l}\text { Hot water } \\
\text { cauldron } \\
\text { no } 1\end{array}$ & $\begin{array}{c}103,2 \\
\mathrm{Gcal} / \\
\mathrm{h}\end{array}$ & $\begin{array}{l}\text { ICPET } \\
\text { Buchar } \\
\text { est } \\
\text { IMUC } \\
\text { Pitești }\end{array}$ & $\begin{array}{l}19 \\
99\end{array}$ & $\begin{array}{c}\text { Blac } \\
\mathrm{k} \\
\text { coal } \\
\text { / gas }\end{array}$ \\
\hline $\begin{array}{l}\text { Start-up } \\
\text { heating } \\
\text { plant } \\
\text { (cauldron6 } \\
+ \text { cauldron } \\
\text { 7) }\end{array}$ & $\begin{array}{c}2 \mathrm{X} \\
20 \mathrm{t} / \mathrm{h}\end{array}$ & $\begin{array}{l}\text { LOSS- } \\
\text { Germa } \\
\text { nia }\end{array}$ & $\begin{array}{l}20 \\
10\end{array}$ & Gas \\
\hline
\end{tabular}

The sums invested to ensure the operation of Paroseni central heating power plant are the following: the rehabilitation of the energy unit no. 4 of 150 MW - 496,363,713.84 lei; installation of the start-up heating plant for group 4 of $150 \mathrm{MW}-10,854,273.20$ lei; the installation of a steam cauldron of $270 \mathrm{t} / \mathrm{h}$ and of a hot water cauldron of $100 \mathrm{Gcal} / \mathrm{h}$ 206,127,934.26 lei.

The finalisation of the investments for the environment, respectively "The installation for the desulphurisation of the burning gas used for group 4 of $150 \mathrm{MW}$ and the HWC of 100 Gcal/h" (GDI) and "The change of the present technology for the collection, transport and storing of cinder and ash" (DSS), have led to the complete fulfilment of the environment conditions imposed by the European Directive $\mathrm{EC} / 2010 / 75$. The amounts of money invested to ensure the future operation of Paroseni CHPP are the gas desulphurisation installation and the dense sludge system (GDI+DSS), namely 65,300,000.00 Euro.

The entire Paroseni CHPP was designed to operate on black coal mined in Jiu Valley. Moreover, its desulphurisation installation and the dense sludge system (finalised investments) were designed and built taking into consideration the fact that the energy unit no. 4 of the plant shall be operational using only Jiu Valley black coal. Tables 1 and 2 bring forward the values for the electricity and heat produced by the plant, while table 3 presents the data related to fuel, i.e. black coal, consumption.

Table 2. Produced electricity (MWh):

\begin{tabular}{|c|c|c|c|c|}
\hline 2007 & 2009 & 2011 & 2013 & 2015 \\
\hline 714151 & 906556 & 987724 & 928647 & 855422 \\
\hline
\end{tabular}

Table 3. Supplied heat (Gcal):

\begin{tabular}{|c|c|c|c|c|}
\hline 2007 & 2009 & 2011 & 2013 & 2015 \\
\hline 117570 & 182457 & 179712 & 216465 & 187609 \\
\hline
\end{tabular}

Table 4. Black coal consumption

\begin{tabular}{|c|c|c|}
\hline & tone & $\mathrm{Q}_{\mathrm{i}}(\mathrm{kcal} / \mathrm{kg})$ \\
\hline 2007 & 517076 & 3574,28 \\
\hline 2009 & 640532 & 3615,12 \\
\hline 2011 & 658879 & 3690,15 \\
\hline 2013 & 664525 & 3758,69 \\
\hline 2015 & 620330 & 3627,36 \\
\hline
\end{tabular}




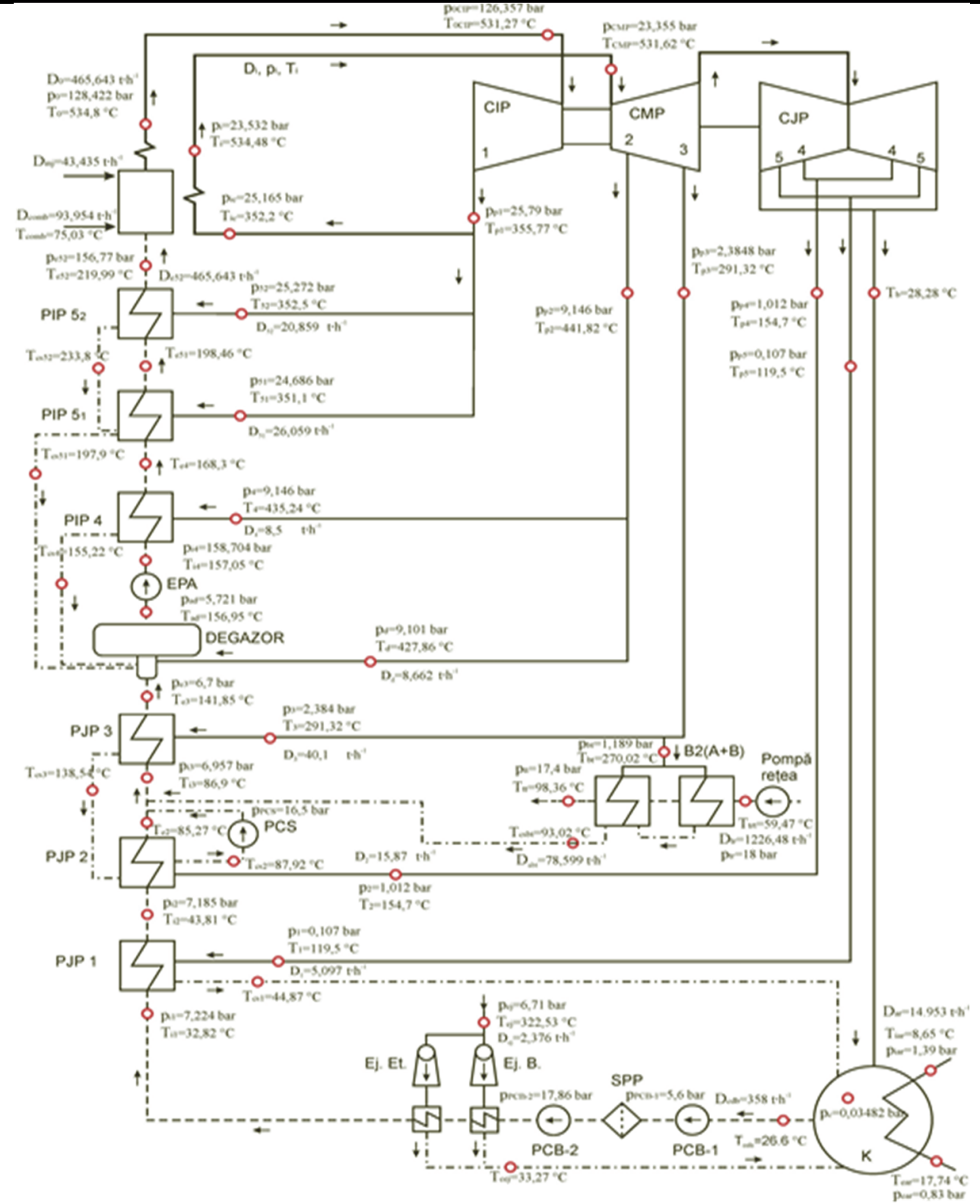

Figure 3. Diagram for the thermal-energetic balance steam generator - turbine, $130 \mathrm{MW}$, cogeneration

Table 5. Energetic indexes

\begin{tabular}{|l|l|}
\hline Live steam flow, $\mathrm{t} \cdot \mathrm{h}^{-1}$ & 465,643 \\
\hline Heating steam flow, $\mathrm{t} \cdot \mathrm{h}^{-1}$ & 78,599 \\
\hline Internal processes steam flow, $\mathrm{t} \cdot \mathrm{h}^{-1}$ & 14 \\
\hline Mechanical efficiency, \% & 98,54 \\
\hline Generator efficiency, \% & 98,96 \\
\hline Cauldron efficiency, \% & 92,78 \\
\hline Cauldron specific fuel consumption, (g c.c.) $\cdot\left(\mathrm{kg}\right.$ steam) ${ }^{-1}$ & 105,94 \\
\hline
\end{tabular}


108 ARA Journal of Sciences, nr 2 (2018)

\begin{tabular}{|l|l|}
\hline Specific heat consumption of the turbine, $\mathrm{kJ}^{\cdot \mathrm{kJ}^{-1}}$ & 2,194 \\
\hline CPT, MW & 12,825 \\
\hline Raw energetic efficiency, \% & 48,25 \\
\hline Gross energetic efficiency, \% & 34,25 \\
\hline Pipes efficiency, \% & 99 \\
\hline Specific heat consumption for electricity production for the group, $\mathrm{kJ} \cdot \mathrm{kWh}^{-1}$ & 9245,55 \\
\hline Gross heat consumption for electricity production for the group & 10510,32 \\
\hline Specific fuel consumption for the group, $(\mathrm{g}$ c.c. $) \cdot(\mathrm{kWh})^{-1}$ & 311,749 \\
\hline Specific steam consumption of the turbine, $\left(\mathrm{kg}\right.$ steam) $\cdot(\mathrm{kWh})^{-1}$ & 2,943 \\
\hline $\begin{array}{l}\text { Conventional fuel specific consumption for the production of heat, }(\mathrm{kg} \text { c.c.) } \\
\text { Gcal }{ }^{-1}\end{array}$ & 159,49 \\
\hline $\begin{array}{l}\text { Specific consumption of conventional fuel for the production of electricity in in } \\
\text { a heat operation mode, }(\mathrm{g} \text { c.c. }) \cdot \mathrm{kWh}^{-1}\end{array}$ & 137,16 \\
\hline
\end{tabular}

The main activities and results: products and services

The operation of the plant may be described by the following flows of technological materials: the fuel and combustion air flow, operational water flow, reactive flow, steam flow, cooling water flow, burnt gases flow, cinder and ash flow.

Energetic performance parameters for the $150 \mathrm{MW}$ group

The energetic performances of the 150 MW group were determined using an energetic balance for cogeneration at different load levels. The main operational parameters were therefore calculated, energetic efficiency and the specific consumptions of the steam generator, turbine and of those of the energy unit, in order to emphasise their energetic characteristics and to analyse if they meet the designed parameters. A series of results regarding the cogeneration operation at 130 MW and thermal load 47,75 Gcal/h are brought forward.

The energetic parameters of the $150 \mathrm{MW}$ group comprised in figure 3 were determined based on the data presented in the simplified thermal diagram.

\section{Conclusions}

Paroseni central heating power plant represented the first $150 \mathrm{MW}$ group built in the country and the largest of its time, being therefore the first central heating power plant in the country with an installed power of 300 $\mathrm{MW}$, and subcritical parameters. It has been in operation since 1953, initially supplying only electricity in SEN, being modernised afterwards and becoming a central heating power plant. At present, the $150 \mathrm{MW}$ group is rehabilitated and operational, being the only group operating on black coal which meets all the environmental conditions, and the European electricity efficiency parameters.

\section{References}

[1]. D.C PETRILEAN.,et al, Scientific Research Contract no. 3/14.01.2015 "Preparation of performance measurements and technical report for the determination of some indicators necessary for the qualification of the production of electricity in high efficiency cogeneration for the Energy Unit no. 4 of 150 MWh of C.E.H. Corporation - Power Plant Paroseni. Contracting Parties: C.E.H. S.A beneficiary, University of Petroşani - services provider

[2]. https: //uzinaparoseni.wordpress.com/ 